\title{
Anti-Diabetic Plants Used in Cameroon with a Potential of Endogenous Renewal Pancreatic B-Cells Important in the Management of Diabetes
}

ISSN: 2578-0263

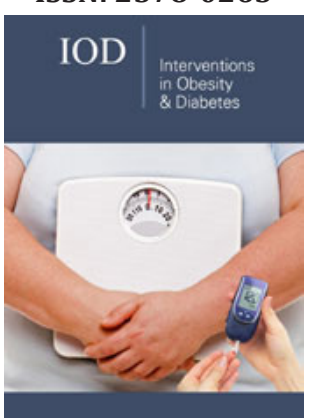

*Corresponding author: Tsabang Nolé, Higher Institute of Environmental Sciences,TsambangDjeufack Wilfried Lionel, Centre de Cardiologie et Medical, Yaounde, Cameroon

Submission: 制 September 28, 2020

Published: 漈January 08, 2021

Volume 4 - Issue 4

How to cite this article: Tsabang Nolé Anti-Diabetic Plants Used in Cameroon with a Potential of Endogenous Renewal Pancreatic ß-Cells Important in the Management of Diabetes. Interventions Obes Diabetes 4(4). IOD.000595. 2021. DOI: 10.31031/IOD.2021.04.000595

Copyright@ Tsabang Nolé. This article is distributed under the terms of the Creative Commons Attribution 4.0 International License, which permits unrestricted use and redistribution provided that the original author and source are credited.

\section{Tsabang Nolé*}

Higher Institute of Environmental Sciences, TsambangDjeufack Wilfried Lionel, Centre de Cardiologie et Medical, Cameroon

\begin{abstract}
Type 1-diabetes is the result of pancreatic $\beta$ cells autoimmune destruction, whereas Type 2 -diabetes is the result of the mixture of insulin resistance and inadequate insulin excretion. Thus, for both diabetes types, the functional mass of $\beta$ cells is not enough for the control of blood glucose. These two pathologies touch approximately 200 million people worldwide today. Type 2-diabetes is globally a huge economic problem. According to the International Diabetes Foundation 382 million people were diagnosed with diabetes in 2013 and this number is expected to increase to 592 million by 2035 . Beta-cell regeneration is a natural procedure that produces new beta cells, which synthesize and discharge insulin in the pancreas. Users of plants like local therapists are interest in taking advantage of these mechanisms to select plants species for preventing, treating or curing diabetes. Objective and methods: The purpose of the present article is to identify from medicinal plant species published by Cameroonians those with the potential to renew the pancreatic ß-cells mass, through bibliographic research in Google, PubMed, Google Scholar databases. Results: Over 210 plants are reported to have antidiabetic effects in Cameroon. About 12 plants among them have been confirmed as antidiabetic plants. Among other plants used for the treatment of diverse diseases 6 have beta cells regeneration activity. However, few clinical trials haveevaluated the effectiveness and safety of these plants. Many studies have shown that 9 plants presented pancreatic beta cells regeneration outcomes. Amongst them, Bidens pilosa exerted antidiabetic action via the regulation of $\beta$-cell function. Annona muricata have reduced oxidative stress of pancreatic $\beta$-cells of streptozotocin induced diabetic rats by increasing the $\beta$-cells number. Alcoholic extracts of whole Catharanthus roseusplant has been released diabetes through $\beta$ cell regeneration. Conclusion: Modern clinical evaluations of recorded ethnopharmacological medicine will be investigated to estimate their efficacy and safety in humans and then use them to prepare herbal medicines worldwide.
\end{abstract}

Keywords: Anti-diabetic plants; Potential antihyperglycemic plants; Bioactive antidiabetic compounds; Pancreatic beta cells regeneration; Cameroon

\section{Introduction}

\section{Diabetes and late healthcare in developing countries}

Diabetes is a chronic metabolic, genetic and environmental worldwide disease characterized by hyperglycemia. This high blood glucose concentration is due to insufficient synthesis of endogenous insulin by the pancreas beta cells for the type- 1 diabetes, or impaired insulin production and/or activity for type-2 diabetes [1]. So type- 1 diabetes is an autoimmune disease due to the destruction of T-cell mediated located in the pancreas beta cells. Yet type- 2 diabetes is characterized by a development of insulin resistance and beta cell dysfunction. These two metabolic disorders are strongly associated with obesity and a sedentary lifestyle [2,3]. In many developing countries diabetes was considered as a disease of wealth countries. That is why three decades ago, undiagnosed diabetic patients perished, killed by this insipid and complicated pathology [4,5]. Face to this undesirable situation many scientific, administrative and social efforts were done in Cameroon to combat diabetes. The recrudescence of the prevalence of diabetes, especially amongst towns' dwellers, the over expensive cost and the long duration of treatment oblige Cameroonians through local therapists to utilize medicinal plants to fight this symptomatic disease. The plants used were selected amongst medicinal plants which were used from centuries for the treatment of various human ailments. Herbal preparations because of its cost effective, safety and substitution for the treatment of diseases are also strongly used for diabetes mellitus [6]. The purpose of the present article is to identify from medicinal plants published by Cameroonians those which 
are potential renewal of pancreatic ß-cells, through bibliographic research in Google, PubMed, Google Scholar databases. Responses to the following research questions are needed to better understand the function of pancreatic beta cells in the treatment of diabetes. What are beta cells? Where are they located? What is their role in the processes of hyperglycemia regulation? What is the cause of their destruction? Are plants able to regenerate them? The commentary below clearly provides answers to these questions in a succinct and precise manner.

\section{Location of pancreas}

The pancreas is a glucose controlling organ, located bellow stomach and before small intestine in the middle of duodenum. The beta cells which secrete insulin are located is in this organ.

\section{Exocrine and endocrine functions}

The pancreas is a complex organ exercising exocrine and endocrine functions. The exocrine pancreas is made up of acinar cells that produce and secrete digestion enzymes that will be transported to the intestine through the pancreatic duct system. The endocrine pancreas, which controls glucose homeostasis, is organized into micro-organs (the islets of Langerhans), dispersed throughout the pancreatic tissue and composed of five cell types, $\alpha$, $\beta, \delta, \varepsilon$ and PP respectively secreting glucagon, insulin, somatostatin, ghrelin and the pancreatic polypeptide. Insulin-secreting cells being by far the most numerous, following by $\alpha$ cells.

A closer look at the islets of Langerhans reveals that these contain 2 principal types of cells: $\alpha$ cells at the periphery and $\beta$ cells at the center. The pancreas secretes two hormones: insulin and glucagon. Insulin is produced by $\beta$ cells and glucagon is made by $\alpha$ cells. As the islets of Langerhans are richly vascularized, these cells directly release hormones into the blood. The pancreas therefore has a double function: the secretion of digestive enzymes and the production of hormones released in the blood allowing the regulation of blood glucose (Figure 1).

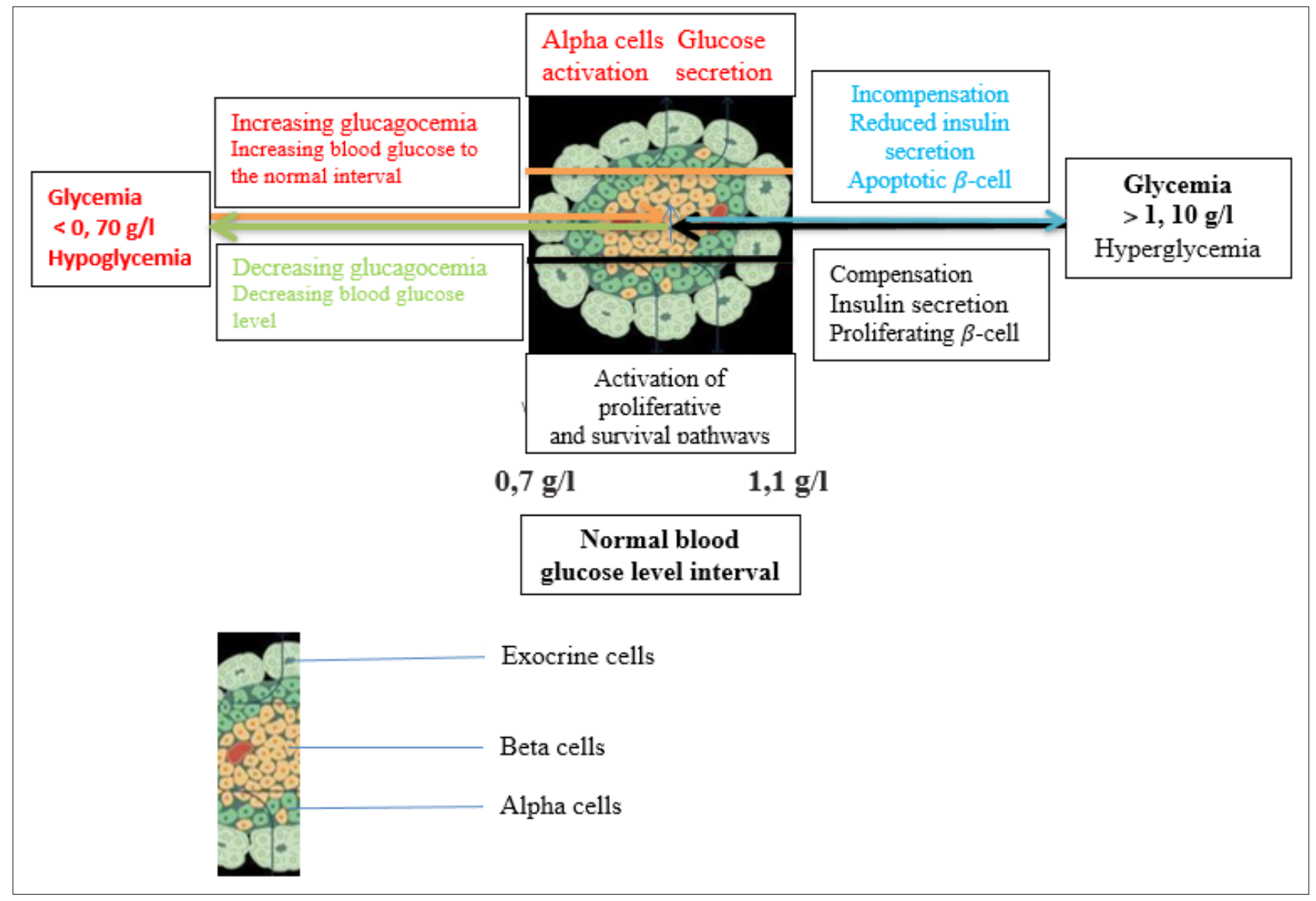

Figure 1: Glycaemia pancreatic regulation.

\section{Insulin is a blood sugar lowering hormone}

$\beta$ cells are directly sensitive to blood sugar. The higher the blood sugar, the more insulin released. Blood insulin works on cells using specific protein receptors in their plasma membranes: these are target cells. Insulin does not enter these cells. Insulin acts on a very large number of target cells:
a. liver cells,
b. muscle cells,
c. adipose tissue cells (adipocytes), 
d. more other organs, except cells of the nervous system.

e. insulin has several roles:

f. promote the penetration of glucose into the liver,

g. favor its use in cellular respiration in the muscles,

h. stimulates glycogen genesis and inhibits glycogenolysis (storage of glucose in the form of increased glycogen in the liver),

i. stimulates lipogenesis from glucose and inhibits the hydrolysis of fats. In general, insulin therefore promotes the storage of glucose and its use; it therefore lowers the level of glucose in the blood. It is a hypoglycemic hormone. It is the only hypoglycemic hormone the body has (Figure 1).

\section{Glucagon: A hyperglycemic hormone}

The cells secrete glucagon (polypeptides of 29 amino acids). They lower the blood sugar. Glucagon also binds to specific receptors on the membranes of these target cells, which are only liver cells. Glucagon increases blood sugar; it is a hyperglycemic hormone. Glucagon works by stimulating glycogenolysis, increased release of glucose into the blood. The body has other hyperglycemic hormones like adrenaline, cortisol... (Figure 1).

\section{Insulin and glucagon are antagonistic hormones}

When the blood sugar is between $0,7 \mathrm{~g} / \mathrm{L}$ and $1,1 \mathrm{~g} \cdot \mathrm{L}^{-1}$, the secretions of insulin and glucagon are low: this is called basal secretions. If the blood sugar raises, the insulin level increases, the glucagon level decreases, the insulin/glucagon ratio becomes very high, and glucose is stored. If the blood sugar goes down, it's the inverse that will produce (Figure 1).

\section{Antidiabetic bioactive compounds}

This work aims to research bioactive compounds responsible of plant pancreatic beta cells regeneration and regulation of oxidative stress.

\section{Pancreatic beta regeneration of bioactive compounds}

These substances are effective in the treatment of type 1-diabetes, by stimulating the beta cells production and insulin releasing by these special cells. More an antidiabetic plant has a strong number or concentration of these compounds more the plant can potentially stimulate the synthesis of beta cells.

\section{Antioxidative stress active compounds}

Compounds of this group can act as an effective insulin sensitizing and insulinotropic agent. That means antioxidative stress substances increase glucose-stimulated insulin secretion.

\section{Importance of ethnopharmacology}

As manifold conventional antihyperglycemic drugs many antidiabetic plants are used in Cameroon, but diabetes still a health problem. Numerous local therapists do not pose correct diabetic diagnostic and its complications. They do not know well the strong variety of natural hypoglycemic substances found in ethnomedical medicines, used widely in African, South American, and Asian traditional medicine for diabetes management. Therefore the identification of plants or antidiabetic compounds with pancreatic beta cells regeneration will help them to use appropriate herbal medicines for type 1-diabetes. As a result of over-nutrition and progressively inactive lifestyles, type 2 Diabetes has reached epidemic proportions. Modern therapies, while effective, are restricted. These restrictions, the frightening upsurge in the prevalence of diabetes, and the climbing cost of managing diabetes and its complications emphasizes an urgent need for innocuous, more efficient and affordable alternative treatments [7]. Some bioactive plants extracts and isolated compounds such as, betapyrazol-1-ylalanine, cellobioside, cinchonain Ib, christinin-A, dehydrotrametenolic acid, epicatechin, epigallocatechin gallateleucocyandin 3-0-beta-d-galactosyl leucopelargonidin-3O-alpha-L rhamnoside, glycyrrhetinic acid, roseoside strictinin, isostrictinin, pedunculagin, show significant insulinomimetic and antidiabetic activity with more efficacy than conventional hypoglycaemic agents [8]. Insulin therapy has been assessed with significance to enhancement in inflammatory conditions but the defect in the anti-aging gene Sirt 1 and diabetic mitophagy still persists with the introduction of nonalcoholic fatty liver disease and various organ diseases [9]. Therefore recorded species can be highlighted by their possible integration into the healthcare system.

\section{Materials and Methods}

\section{Criteria of plants inclusion}

Plants admitted in this work must be used in Cameroon and reencountered in publications authorized by Cameroonians on diabetes. Plants for the management of type 1-diabetes were more indorsed. Extracts of these plants or compounds isolated from them showed diverse antihyperglycemic activities especially in type 1-diabetes. The review was performed in Google, Google Scholar and Pubmed since five years.

\section{Ethno pharmacological doses}

Standardized doses of recipes were calculated by deduction from experimental doses used to treat in vivo alloxan-induced or streptozotocin-induced diabetic rats or diabetic patients in cases of clinical trials. For example a patient of $60 \mathrm{~kg}$ body weight would take 60 times the quantity of abstracts administrated for a kilogram body weight of experimental animals. Generally the dose is related to the weight of a given person.

\section{Authentication of plants identification}

Plants taxonomical accepted names or their synonyms were searched in African Plants database.

\section{Results}

Over 210 plants were supposed to have antihyperglycemic properties in Cameroon [10-30]. About 13 plants among them have been confirmed as antidiabetic plants [10-30]. Among other plants used for the treatment of diverse diseases 6 have beta 
cells regeneration activity. However, few clinical trials have ever evaluated the effectiveness and safety of these plants [26,29]. Many studies have shown that 9 plants presented pancreatic beta cells regeneration. Amongst them Bidens pilosa exerted antidiabetic action via the regulation of $\beta$-cell function [31-35], Annona muricata have reduced oxidative stress of pancreatic $\beta$-cells of streptozotocin induced diabetic rats by increasing the number of insulin immunoreactive $\beta$-cells and their protection against degeneration. In this review 9 plants were admitted. They belonged to Cameroonians' publications on diabetes randomized selected in all regions. Their strategy to regenerate pancreatic beta cells [3655], significant to manage diabetes is presented in Table 1.

Table 1 : Existing pancreatic beta cell regeneration' mechanisms of antidiabetic plants commonly used in Cameroon effects. SNPAPRP: Scientific names of potential antidiabetic plants and references of their publications; PPSERPBC: Pharmacological previous scientific evidence of the regeneration of pancreatic beta cell by each plant recorded; PEPPEU: Experimental doses of plants' extracts or isolated; PPCDED: Proposed posology calculated by deduction from the experimental doses used to treat in vivo alloxan-induced or streptozotocin-induced diabetic rats or diabetic patients in case of clinical trials.

\begin{tabular}{|c|c|c|c|}
\hline SNPAPRP & $\begin{array}{c}\text { Common and Vernacular } \\
\text { Names }\end{array}$ & PPSERPBC & $\begin{array}{l}\text { PEPPEU and PPC- } \\
\text { DED }\end{array}$ \\
\hline $\begin{array}{l}\text { Annona muricata } \\
\text { Lin. (Annonaceae) }\end{array}$ & $\begin{array}{l}\text { Corrossol, guanabana, } \\
\text { soursop }\end{array}$ & $\begin{array}{c}\text { Annona muricata have reduced oxidative stress of pancreatic } \beta \text {-cells of } \\
\text { streptozotocin induced diabetic rats. This reduction was confirmed by the } \\
\text { increased number of insulin immunoreactive } \beta \text {-cells and their protection } \\
\text { against degeneration [36]. }\end{array}$ & $\begin{array}{c}50,100 \text { and } 200 \mathrm{mg} / \\
\text { kg body weight }\end{array}$ \\
\hline $\begin{array}{l}\text { Bidens pilosa Lin. } \\
\quad(\text { Asteraceae })\end{array}$ & $\begin{array}{c}\text { Blackjack, cobbler's pegs, } \\
\text { hairy beggarticks, Spanish } \\
\text { needles (English). Sornet, } \\
\text { piquant noir, bident } \\
\text { hérissé, herbe aiguille, } \\
\text { herbe villebague (French). }\end{array}$ & $\begin{array}{l}\text { The research of Lai et al. showed that treatment of diabetic patients with a } \\
\text { Bidens pilosa formulation ( } 400 \mathrm{mg} / \text { day) for three months decreased fasting } \\
\text { blood glucose concentration and hemoglobin A1c (HbA1c), but augmented } \\
\text { fasting serum insulin in healthy subjects [35]. Treatment with the Bidens } \\
\text { pilosa formulation significantly improved pancreatic beta cell function of } \\
\text { the study members compared with homeostatic model assessment beta } \\
\text { (HOMA- } \beta \text { ) values. Consequently, Bidens pilosa or it active compound deriv- } \\
\text { atives cytopiloyne could be potential mediators to manage type } 2 \text { diabetes } \\
\text { by stimulating pancreatic beta cells [36]. }\end{array}$ & $\begin{array}{c}\text { (400mg/day) body } \\
\text { weight for three } \\
\text { months }\end{array}$ \\
\hline $\begin{array}{l}\text { Catharanthus roseus } \\
\text { Lin. (Apocynaceae) }\end{array}$ & $\begin{array}{l}\text { Pervenche de Madagas- } \\
\text { car, rose amère (French). } \\
\text { Vinca, Madagascar pe- } \\
\text { riwinkle, rosy periwinkle } \\
\text { (English). }\end{array}$ & $\begin{array}{l}\text { The administration of alloxan in rats to induce diabetes provokes hyper- } \\
\text { glycemia by increasing the blood glucose level during seven days experi- } \\
\text { mental period. The treatment by Catharanthus roseus has decreased the } \\
\text { level of glucose in diabetic rats. The number of } \beta \text { cell increased despite } \\
\text { its destruction. It was concluded that regeneration of pancreatic } \beta \text { cells } \\
\text { following destruction by alloxan may be the primary cause of the lowering } \\
\text { of hyperglycemia [37]. Therefore alcoholic extracts whole Catharanthus } \\
\text { roseus plant has been released diabetes through } \beta \text { cell regeneration [38]. }\end{array}$ & $\begin{array}{l}250 \mathrm{mg} / \mathrm{kg} \text { body } \\
\text { weight. }\end{array}$ \\
\hline $\begin{array}{l}\text { Capsicum annuum } \\
\text { Lin. (Solanaceae) }\end{array}$ & $\begin{array}{l}\text { Chili pepper, Aromatic } \\
\text { pepper Piment, Poivron }\end{array}$ & $\begin{array}{l}\text { Capsicum annuum is a spice plant with fruit rich in the major compound } \\
\text { called Capsaicin [39]. Administration of capsaicin to Zucker diabetic fatty } \\
\text { streptozotocin-induced (ZDF) rats decreased blood glucose concentrations } \\
\text { and augmented plasma insulin levels compared with those of switch mice } \\
\text { [40]. Capsaicin in dietary supplementation of red fruits powder for two } \\
\text { weeks to this treated rats nourished a high-fat diet did not lower the blood } \\
\text { glucose concentration, but the plasma insulin level was greater in these } \\
\text { rats than that in the control group, signifying that capsaicin holds an insuli- } \\
\text { notropic effect rather than hypoglycemic upshot [39,41]. But clinical trial is } \\
\text { needed to determine its mechanism in diabetic patients. }\end{array}$ & $\begin{array}{l}150 \text { or } 300 \mathrm{mg} / \mathrm{kg} \\
\text { body weigh }\end{array}$ \\
\hline $\begin{array}{l}\text { Carica papaya Lin. } \\
\quad(\text { Caricaceae })\end{array}$ & $\begin{array}{c}\text { papayer, "pied-papaye” } \\
\text { Papaya }\end{array}$ & $\begin{array}{l}\text { Carica papaya leaves show antidiabetic activity and bioactive phytochemi- } \\
\text { cals are speculated to be Flavonoids, alkaloids, saponins, and tannins. The } \\
\text { leaves }(0.75 \mathrm{~g} 1.5 \mathrm{~g} / 100 \mathrm{~mL}) \text { aqueous extract of Carica papaya significantly } \\
\text { decreased plasma blood glucose concentration, serum cholesterol, and se- } \\
\text { rum triacylglycerol in streptozotocin-induced and alloxan-induced diabetic } \\
\text { rats [41]. Histological discoloration of the pancreatic islets of Langerhans } \\
\text { presented that these extracts significantly decreased the regeneration of } \\
\text { pancreatic beta cells }[42,43] . \text { Future research is required for elucidating } \\
\text { the antidiabetic effect of Carica papaya in humans. }\end{array}$ & $\begin{array}{c}0.75 \mathrm{~g} 1.5 \mathrm{~g} / 100 \mathrm{~mL}) \\
\text { aqueous extract }\end{array}$ \\
\hline
\end{tabular}




\begin{tabular}{|c|c|c|c|}
\hline $\begin{array}{c}\text { Camellia sinensis } \\
\text { (Theaceae) } \\
\text { Coffea arabica Lin. } \\
\text { and Coffea canepho- } \\
\text { ra Pierre } \\
\text { Syn. C. robusta Lindl. } \\
\text { Ex De Will) (Rubia- } \\
\text { ceae) }\end{array}$ & $\begin{array}{l}\text { Thé vert, Théier (French), } \\
\text { Tea, green tea (English). } \\
\text { Café arabica. Caféier } \\
\text { (French), Robusta coffee } \\
\text { (French) }\end{array}$ & $\begin{array}{c}\text { Caffeine is antibiabetic bioactive compound isolated from Camellia sinen- } \\
\text { sis, Coffea arabica and Coffea robusta. So it has been demonstrated that } \\
\text { the treatment with } 0.01 \% \text { caffeine solution in } 90 \% \text { pancreatectomized } \\
\text { diabetic rats for } 12 \text {-week decreased body weight, fats, and lowered insulin } \\
\text { resistance and boosted glucose-stimulated insulin secretion and beta-cell } \\
\text { hyperplasia [44]. }\end{array}$ & $\begin{array}{l}100 \mathrm{mg} / \mathrm{kg} \text { body } \\
\text { weight } / \mathrm{day} \\
63 \text { and } 93 \mathrm{mg} / \mathrm{kg} \\
\text { body weight }\end{array}$ \\
\hline $\begin{array}{l}\text { Elephantopus scaber } \\
\text { Lin. (Asteraceae) }\end{array}$ & Elephant's Foot & $\begin{array}{l}\text { The acetone extract of this plant showed a significant reduction in blood } \\
\text { glucose concentration by increasing insulin sensitivity, augmenting glucose } \\
\text { dependent insulin secretion and stimulating regeneration of beta cells in } \\
\text { islets of Langerhans in pancreas of streptozotocin-induced diabetic rats } \\
\text { [45]. }\end{array}$ & $\begin{array}{c}\text { Leaf extracts }(0.3 \mathrm{~g} / \\
\mathrm{kg} \text { body weight) for } \\
12 \text { weeks }\end{array}$ \\
\hline $\begin{array}{c}\text { Momordica charantia } \\
\text { Lin. (Curcubitaceae) }\end{array}$ & $\begin{array}{l}\text { bitter guard, karela, or } \\
\text { balsam pear }\end{array}$ & $\begin{array}{l}\text { Diabetes treatment with a water extract of Momordica charantia prevent- } \\
\text { ed alloxan-induced pancreatic beta cell apoptosis and improved insulin } \\
\text { emission in HIT-T15 cells [46]. The treatment with fruit juice of this plant } \\
\text { showed a significant reduction of blood glucose level and increased rate } \\
\text { of plasma insulin in diabetic rats. The observed actions were outstanding } \\
\text { to an upsurge in the number of beta pancreatic cells in cured animals } \\
\text { compared to untreated one. The principal phytochemical such as momor- } \\
\text { dicin, charantin, and other compounds such as galactose-binding lectin and } \\
\text { insulin-like protein found in several parts of this plant have been revealed } \\
\text { insulin mimetic effect [47,48]. } \\
\text { Momordica charantia increases the renewal of some cells in the pancreas } \\
\text { or may permit the recovery of partially destroyed cells and stimulates } \\
\text { pancreatic insulin discharge [49]. }\end{array}$ & $\begin{array}{c}0.25,0,50 \text { and } \\
0.75 \mathrm{mg} / \mathrm{kg} \text { body } \\
\text { weight }\end{array}$ \\
\hline $\begin{array}{c}\text { Moringa oleifera } \\
\text { Lam. synonym: Mor- } \\
\text { inga pterygosperma } \\
\text { Gaertner (Moringa- } \\
\text { ceae) }\end{array}$ & $\begin{array}{l}\text { Drumstick, horseradish } \\
\text { tree (English); mouroun- } \\
\text { gue, ben ailée, moringa } \\
\text { ailée (Fr); maranga, } \\
\text { paraíso }\end{array}$ & $\begin{array}{l}\text { Two concentrations (150 and } 300 \mathrm{mg} / \mathrm{kg} \text { body weight) of methanolic pods } \\
\text { extract of Moringa oleracea, administrated in streptozotocin-induced } \\
\text { diabetic rats showed a significant decrease in serum glucose rate and nitric } \\
\text { oxide levels, with a simultaneous upsurge in serum insulin and protein lev- } \\
\text { els. Additionally, a histological pancreas examination showed that Moringa } \\
\text { oleifera treatment significantly reversed the histopathological damage that } \\
\text { occurred to islet cells by induced diabetes. The Moringa oleifera leaves con- } \\
\text { sumption by alloxan-induced diabetic rats, showed a hypoglycemic/upshot } \\
\text { and prevented body weight loss [50]. }\end{array}$ & $\begin{array}{c}150 \text { and } 300 \mathrm{mg} / \mathrm{kg} \\
\text { body weight }\end{array}$ \\
\hline $\begin{array}{l}\text { Persea americana } \\
\text { Lin. (Lauraceae) }\end{array}$ & $\begin{array}{c}\text { Avocatier, avocat (French) } \\
\text { Avocado, tree, Pear tree ( } \\
\text { English) }\end{array}$ & $\begin{array}{l}\text { The hydroalcoholic leaves extract of Persea americana }(0.15 \text { and } 0.3 \mathrm{~g} / \mathrm{kg} \text {, } \\
\text { body weight, daily for } 4 \text { weeks) decreased blood glucose concentration in } \\
\text { streptozotocin-induced diabetic rats [51]. The extract did not modify the } \\
\text { concentration of plasma insulin. This result suggests that the hypoglycemic } \\
\text { effect was provoked by an extra pancreatic activity, autonomous of insulin } \\
\text { excretion. Additionally, the extract enhanced the metabolic condition of } \\
\text { diabetic rats and augmented body weight. In another study, the aqueous } \\
\text { extract of Persea americana seeds meaningfully reduced glucose rates and } \\
\text { reversed the histoarchitectural damage in alloxan-induced diabetic rats, } \\
\text { comparable to the effects of glibenclamide (an oral antihyperglycemic) } \\
\text { [52]. }\end{array}$ & $\begin{array}{l}0.15 \text { and } 0.3 \mathrm{~g} / \mathrm{kg} \\
\text { body weight }\end{array}$ \\
\hline $\begin{array}{l}\text { Solanum torvum } \\
\text { Swartz } \\
\text { (Solanaceae) }\end{array}$ & Turkey berry & $\begin{array}{l}\text { At } 200 \text { and } 400 \mathrm{mg} / \mathrm{kg} \text { phenolic compounds isolated from Solanum torvum } \\
\text { fruit methanolic extract decreased blood glucose rates in streptozotocin } \\
\text { induced diabetic rats in two principal ways: } \\
\text { 1- augmenting insulin secretion due to regeneration of pancreatic ß-cells, } \\
\text { 2- weakening oxidative stress and regulate enzymes in charge for glucose } \\
\text { metabolism [53]. } \\
\text { Also Methyl caffeate, main principle found in the fruit of Solanum torvum at } \\
\text { concentrations 10, } 20 \text { and } 40 \mathrm{mg} / \mathrm{kg} \text { significantly decreased hyperglycemia } \\
\text { activity in streptozotocin induced diabetic by up regulation of a protein } \\
\text { from the class I transporter family, whose essential role is the transport of } \\
\text { glucose (GLUT4) from plasma to muscle and adipose tissue and renewal of } \\
\text { pancreatic ß-cells in the pancreas [54]. }\end{array}$ & $\begin{array}{c}100 \text { and } 400 \mathrm{mg} / \mathrm{kg} / \\
\text { day, body weight }\end{array}$ \\
\hline
\end{tabular}




\begin{tabular}{|c|c|c|c|c|}
\hline & $\begin{array}{c}\text { Indian almond, tropical al- } \\
\text { mond, Singapore almond, } \\
\text { country almond, Malabar } \\
\text { almond, sea almond (En- } \\
\text { Terminalia catappa), badamier ; aman- } \\
\text { dier-pays (Guadeloupe, } \\
\text { Lin. (Combretaceae): } \\
\text { Martinique), amandier des } \\
\text { Indes (Haït), amandier } \\
\text { de Cayenne (Guyane) } \\
\text { (French) }\end{array}$ & $\begin{array}{c}\text { Three extracts of Terminalia catappa fruits including petroleum ether, } \\
\text { methanol and aqueous extract administrated in alloxan-induced diabetic } \\
\text { rats produced a significant antihyperglycemic effect at dose levels of } 1 / 5 \\
\text { of their lethal doses. The reduction of blood glucose level may be due to } \\
\text { pancreatic } \beta \text {-cells regeneration [55]. }\end{array}$ & $\begin{array}{c}\text { 195, and 210mg/kg, } \\
\text { body weight }\end{array}$ \\
\hline
\end{tabular}

\section{Discussion}

Extracts of recorded plants and/or their bio actives compounds play an antidiabetic role by alleviating oxidative stress (Annona muricata, Solanum torvum), and $\alpha$-glucosidase activity, improving endothelial dysfunction, modulating cytokine expression diabetesinduced damages of neural cells (Bidens pilosa, Carica papaya, Annona muricata) and provoking, ameliorating insulin resistance, (Momordica charantia) suppressing hyperglycemia (Persea Americana, Momordica charantia), improving hyperglycemic complications (Carica papaya, Moringa oleifera), regulating signaling pathway involving in diabetes, enhancing immunity, alleviating pancreatic $\beta$-cells regeneration (Elephantopus scaber, Momordica charantia, Solanum torvum and Terminalia catappa). The antidiabetic effect of plants depends on the bioactive compounds in each plant. It is important to isolate purified individual bioactive compounds so as to test their antidiabetic effect individually. This will help to clarify the principal antidiabetic components in plants and be interesting for improvement of plant processing. The chemical composition of plants varies with the plant cultivars, the processing of compounds isolation and conservation, which lead to unpredictable antidiabetic results between various tests using plants from various habitats. Bioavailability is an important factor influencing the pharmaceutical effects of plants on diabetes [56]. Tea and its extract play all these antidiabetic roles. For these reasons the daily consumption of at least three cups of tea reduced the risk of type 2-diabetes by approximately $42 \%$ [57]. The major chemical constituents in unfermented tea are catechins and caffeine, while in semi-fermented and fully fermented tea theaflavins, thearubigins and caffeine preponderate. Catechins, caffeine and theaflavins have been long-established to hold a comprehensive range of biological actions [56,58]. Recorded plants with insulinomimetic activity include the following: Camellia sinensis and Catharanthus roseus [3]. The bioactive compounds from the antidiabetic plants described that have major effects on the pancreas and renew pancreatic beta cell mass are: Capsaicin in Capsicum annuum; 3 polyynes or cytopiloyne derivatives in Bidens pilosa [35]; phenylpropanoid esters, flavonoids, quinate, quinic acid, coumarate, caffeate, naringenin and quercetin on synergistic action, isolated from Carica papaya [37]; Epigallocatechin-3-gallate in Camellia sinensis; Momordicin in Momordica charantia; Quercetin Commonly found in recorded plants [6]. Particularly the quercetin in Moringa oleifera leaves has anti-diabetic property by correcting pancreatic betacells dysfunction and insulin resistance, thereby increasing insulin secretion.

All the recorded plants have been reported to either reduce blood glucose concentration or to protect pancreatic $\beta$ cells in diabetic animals. In consequent the development of antidiabetic medicines from these plants and active substances may increasingly receiving attention. But the neurodegenerative diseases such as Parkinson's disease (PD) and Alzheimer's disease with appetite dysregulation, insulin resistance and cell apoptosis can complicate the management of diabetes [38].

\section{Conclusion}

We can conclude that this work has presented a list of antidiabetic plants used in the traditional management of diabetes mellitus that specifically improved pancreatic beta cells regeneration. It disclosed that plants have antihyperglycemic activities and can be used against numerous types of secondary complications of diabetes mellitus. Many antidiabetic active compounds found on plants like caffeine, momordicin, charantin, and other compounds such as galactose-binding lectin and insulinlike protein, have been well characterized. More investigations must be carried out to evaluate the exact mechanism of action of antidiabetic plants and antihyperglycemic active ingredients. It is always believed that plant is safe, but so many plant materials are not safe for the humankind, that's why toxicity study of these plants should also be clarified before ingestion of these plant materials. But food plants may be less toxic. We can also conclude that sociocultural medicine and ethnopharmacology are a huge source of information on safety and medical effects of many recorded plants, used to treat hyperglycemia since early time. Indeed, derive from traditional uses, plants like Coffea arabica, Coffea robusta, Carica papaya and Camellia sinensis possess anti-diabetes activities, officially recognized in one or more world regions. These activities are reinforced by clinical proof and registered in WHO monographs. Therefore these plants must be used with minimum attention $[54,55]$. Nevertheless clinical trials in complex animals and human are required. Before that, these plants need to be bio cultivated far of towns' pollution to avoid xenobiotics [56]. Generally the plans to decrease exposure to xenobiotics are imperative to manage the epidemic for diabetes worldwide [56]. 


\section{Acknowledgment}

The emotional and encouraging assistance from my family is greatly acknowledged.

\section{References}

1. American Diabetes Association (2009) Diagnosis and classification of diabetes mellitus. Diabetes Care 32(1): S62-S67.

2. Olokoba AB, Obateru OA, Olokoba LB (2012) Type 2 diabetes mellitus: A review of current trends. Oman Med J 27(4): 269-273.

3. Oyagbemi AA, Salihu M, Oguntibeju 00, Esterhuyse AJ, Farombi EO (2014) Some selected medicinal plants with antidiabetic potentials. Antioxidant-Antidiabetic Agents and Human Health, Oluwafemi Oguntibeju, IntechOpen.

4. Margaret Chan, Director-General of the World Health Organization (2016) Obesity and diabetes: The slow-motion disaster Keynote address at the $47^{\text {th }}$ meeting of the National Academy of Medicine DirectorGeneral's Office Washington, DC, USA.

5. https://www.worlddiabetesfoundation.org/projects/cameroonwdf16-1429.

6. Ekor M (2014) The growing use of herbal medicines: issues relating to adverse reactions and challenges in monitoring safety. Frontiers in Pharmacology 4: 177.

7. Lankatillake A, Huynh C, Dias DA (2019) Understanding glycaemic control and current approaches for screening antidiabetic natura products from evidence-based medicinal plants. Plant Methods 15: 105.

8. Patel ADK, Prasad SK, Kumar R, Hemalatha S (2012) An overview on antidiabetic medicinal plants having insulin mimetic property. Asian Pac J Trop Biomed 2(4): 320-330.

9. Ian J Martins (2016) Anti-aging genes improve appetite regulation and reverse cell senescence and apoptosis in global populations. Advances in Aging Research 5(1): 9-26.

10. Tsabang N, Fongnzossié E, Keumeze V, Jiofack R, Njamen D, et al. (2017) Ethnomedical and ethnopharmacological study of plants used by indigenous people of cameroon for the treatments of diabetes and its signs, symptoms and complications. J Mol Biomark Diagn 8: 310.

11. Nole T, Lionel TDW, Cedrix TFS, Gabriel AA (2016) Ethnomedical and ethnopharmacological study of plants used for potential treatments of diabetes and arterial hypertension by indigenous people in three phytogeographic regions of Cameroon. Diabetes Case Rep 1(110): 1-9.

12. Martins IJ (2018) Insulin therapy and autoimmune disease with relevance to nonalcoholic fatty liver disease: Nonalcoholic fatty liver disease. Open access peer-reviewed chapter.

13. Jiofack T, Fokunang C, Guedje N, Kemeuze V, Fongnzossie E, et al. (2009) Ethnobotanical uses of some plants of two ethnoecological regions of Cameroon. African Journal of Pharmacy and Pharmacology 3(13): 664684.

14. Tsabang N, Yedjou CG, Tsambang LWD, Tchinda AT, Donfagsiteli N, et al. (2015) Treatment of diabetes and/or hypertension using medicinal plants in Cameroon. Med Aromat Plants (Los Angel) 2: 3.

15. Dibong SD, Mpondo ME, Ngoye A, Priso RJ (2011) Modalities of exploitation of medicinal plants in Douala's region. American Journal of Food and Nutrition 1(2): 67-73.

16. Nole T, Wilfried Lionel TD, Nchafor NV, Stheve Cedrix TF, Delphine D (2016) Diabetes and arterial hypertension resorts of treatments and plants used for their treatments in three phytogeographic areas of Cameroon. IJTCM 1(4): 0045-0059.
17. Kuete V, Efferth T (2010) Cameroonian medicinal plants: Pharmacology and derived natural products. Frontiers in Pharmacology 1: 1-19.

18. Tsabang N, Tsambang LWD, Yedjou CG, Tchounwou PB (2017) Sociocultural contribution to medicinal plants assessment and sustainable development: Case of antidiabetic and antihypertensive plants in Cameroon. Glob Drugs Ther 2(1).

19. Njamen D, Nkeh Chungag BN, Tsala E, Fomum ZT, Mbanya JC, et al. (2012) Effect of bridelia ferruginea (euphorbiaceae) leaf extract on sucroseinduced glucose intolerance in rats. Tropical Journal of Pharmaceutical Research 11(5): 759-765.

20. Fofié CK, Nguelefack Mbuyo EP, Tsabang N, Kamanyi A, Nguelefack TB (2018) Hypoglycemic properties of the aqueous extract from the stem bark of ceiba pentandra in dexamethasone-induced insulin resistant rats. Evid Based Complement Alternat Med.

21. Fofie CK, Wansi SL, Nguelefack Mbuyo EP, Atsamo AD, Watcho P, et al. (2014) In vitro anti-hyperglycemic and antioxidant properties of extracts from the stem bark of Ceiba pentandra. J Complement Integr Med 11(3): 185-193.

22. Fofie KC, Khatekaye S, Nguelefack Mbuyo PE, Kamanyi A, Kamble B, et al. (2018) Insulin sensitizing effect as possible mechanism of the antidiabetic properties of the methanol and the aqueous extracts from the trunk bark of Ceiba pentandra. Diabetes Updates 1(3): 1-6.

23. Paul Désiré DD, Ohandja DY, Tédong L, Asongalem EA, Dimo T, et al. (2007) Antidiabetic effect of ceiba pentandra extract on streptozo-tocininduced non-insulin-dependent diabetic (NIDDM) rats. Afr J Tradit Complement Altern Med 4(1): 47-54.

24. Pierre S, Toua V, Tchobsala, Fernand NTF, Alexandre Michel NN, et al. (2011) Medicinal plants used in traditional treatment of malaria in Cameroon Saotoing. Journal of Ecology and the Natural Environment 3(3): 104-117.

25. Nangue YD, Llorent Martínez EJ, Fernández-de Córdova ML, Ngangoum DAM, Nguelefack TB, et al. (2019) Phytochemical study and anti-inflammatory activity of the roots of Mangifera indica L. in lipopolysaccharide (LPS)-stimulated peritoneal macrophages. Trends in Phytochemical Research 3(1): 53-60.

26. Tsabang N, Lionel W, Djeufack T, Yedjou CG, Tchounwou PB (2019) Importance of food plants in the prevention and treatment of diabetes in Cameroon. Bioactive Compounds in Health and Disease 2(2): 11-26.

27. Dimo T, Rakotonirina SV, Tan PV, Azay J, Dongo E, et al. (2007) Effect of Sclerocarya birrea (Anacardiaceae) stem bark methylene chloride/ methanol extract on streptozotocin-diabetic rats. J Ethnopharmacol 110(3): 434-438

28. Vincent PK Titanji, Denis Zofou, Ngemenya MN (2008) The antimalarial potential of medicinal plants used for the treatment of malaria in Cameroonian folk medicine. Afr J Tradit Complement Altern Med 5(3): 302-321.

29. Telefo PB, Lienou LL, Yemele MD, Lemfack MC, Mouokeu C, et al. (2011) Ethnopharmacological survey of plants used for the treatment of female infertility in Baham, Cameroon. J Ethnopharmacol 136(1): 178-187.

30. Nguelefack TB, Feumebo CB, Ateufacka G, Watchom P, Tatsimo S, et al. (2008) Anti-ulcerogenic properties of the aqueous and methanol extracts from the leaves of Solanum torvum Swartz (Solanaceae) in rats. Journal of Ethnopharmacology 119(1): 135-140.

31. Marles RJ, Farnsworth NR (1995) Antidiabetic plants and their active constituents. Phytomedicine 2(2): 137-189.

32. Chang CL, Liu HY, Kuo TF, Hsu YJ, Shen MY, et al. (2013) Antidiabetic effect and mode of action of cytopiloyne. Evidence-Based Complementary and Alternative Medicine. 
33. Yang WC (2014) Botanical, pharmacological, phytochemical, and toxicological aspects of the antidiabetic plant Bidens Pilosa L. EvidenceBased Complementary and Alternative Medicine.

34. Bartolome AP, Villaseñor IM, Yang WC (2013) Bidens pilosa L. (Asteraceae): botanical properties, traditional uses, phytochemistry, and pharmacology. Evidence-Based Complementary and Alternative Medicine.

35. Lai BY, Chen TY, Huang SH, Kuo TF, Chang TH, et al. (2015) Bidens pilosa formulation improves blood homeostasis and beta cell function in men: A pilot study. Evidence-Based Complementary and Alternative Medicine 2015: 832314 .

36. Matalqah SM, Al-Tawalbeh DM (2019) Medical plants potential against diabetes mellitus: Review article. International Journal of Pharmacognosy 6(2): 39-53.

37. Gorray KC, Baskin D, Brodsky J, Fujimoto WY (1986) Responses of pancreatic B cells to alloxan and streptozotocin in the guinea pig. Pancreas 1(2): 130-138.

38. Aruljothi B, Samipillai SS (2016) Antidiabetic activity of Catharanthus roseus in alloxan induced diabetic rats. Int J Modn Res Revs 4(3): 11211124

39. Islam MS, Choi H (2008) Dietary red chilli (Capsicum frutescens L.) is insulinotropic rather than hypoglycemic in type 2 diabetes model of rats. Phytotherapy Research 22(8): 1025-1029.

40. Gram DX, Ahren B, Nagy I, Olsen UB, Brand CL, et al. (2007) Capsaicinsensitive sensory fibers in the islets of Langerhans contribute to defective insulin secretion in Zucker diabetic rat, an animal model for some aspects of human type 2 diabetes. European Journal of Neuroscience 25(1): 213-223.

41. Miranda Osorio PH, Castell Rodríguez AE, Mancilla JV, Tovilla Zárate CA, Ble Castillo JL, et al. (2016) Protective action of carica papaya on $\beta$-cells in streptozotocin-induced diabetic rats. Int J Environ Res Public Health 13(5): 446.

42. Juarez Rojop IE, Diaz Zagoya JC, Ble Castillo JL, Osorio PHM, Rodriguez AEC, et al. (2012) Hypoglycemic effect of Carica papaya leaves in streptozotocin induced diabetic rats. BMC Complementary and Alternative Medicine 12: 236.

43. Sasidharan S, Sumathi V, Jegathambigai NR, Latha LY (2011) Antihyperglycaemic effects of ethanol extracts of Carica papaya and Pandanus amaryfollius leaf in streptozotocin induced diabetic mice. Natural Product Research 25(20): 1982-1987.

44. Park S, Jang JS, Hong SM (2007) Long-term consumption of caffeine improves glucose homeostasis by enhancing insulinotropic action through islet insulin/insulin-like growth factor 1 signaling in diabetic rats. Metabolism 56(5): 599-607.
45. Rao MU, Sreenivasulu M, Chengaiah B, Reddy KJ, Chetty CM (2010) Herbal medicines for diabetes mellitus: A review. Int J Pharm Tech Res 2(3): 1883-1892.

46. Xiang L, Huang X, Chen L, Rao P, Ke L (2007) The reparative effects of Momordica Charantia Linn. extract on HIT-T15 pancreatic $\beta$-cells. Asia Pacific Journal of Clinical Nutrition 16(1): 249-252.

47. Atkinson MA, Eisenbarth GS (2001) Type 1 diabetes: new perspectives on disease pathogenesis and treatment. The Lancet 358(9277): 221229.

48. Ahmed I, Adeghate E, Cummings E, Sharma AK, Singh J (2004) Beneficial effects and mechanism of action of Momordica charantia juice in the treatment of streptozotocin-induced diabetes mellitus in rat. Molecular and Cellular Biochemistry 261(1): 63-70.

49. Chauhan A, Sharma PK, Srivastava P, Kumar N, Duehe R (2010) Plants having potential antidiabetic activity: A review. Der Pharm Lett 2(3): 369-387.

50. Gupta R, Mathur M, Bajaj VK, Katariya P, Yadav S, et al. (2012) Evaluation of antidiabetic and antioxidant activity of Moringa oleifera in experimental diabetes. J Diabetes 4(2): 164-171.

51. Ezejiofor AN, Okorie A, Orisakwe OE (2013) Hypoglycaemic and tissueprotective effects of the aqueous extract of Persea americana seeds on alloxan-induced albino rats. Malays J Med Sci 20(5): 31-39.

52. Lima CR, Vasconcelos CF, Costa Silva JH, Maranhão CA, Costa J, et al. (2012) Anti-diabetic activity of extract from Persea americana Mill. Leaf via the activation of protein kinase B (PKB/AKT) in streptozotocininduced diabetic rats. J Ethnopharmacol 141(1): 517-525.

53. Gandhi GR, Ignacimuthu S, Paulraj MG, Sasikumar P (2011) Antihyperglycemic activity and antidiabetic effect of methyl caffeate isolated from Solanum torvum Swartz. fruit in streptozotocin induced diabetic rats. Eur J Pharmacol 670(2-3): 623-631.

54. Jaiswal BS (2012) Solanum torvum: A review of its traditional uses, phytochemistry and pharmacology. Int J Pharm Bio Sci 3(4): 104 -111.

55. Nagappa AN, Thakurdesai PA, Venkat Rao N, Singh J (2003) Antidiabetic activity of Terminalia catappa Linn fruits. Journal of Ethnopharmacology 88(1): 45-50.

56. (2018) Increased risk for obesity and diabetes with neurodegeneration in developing countries. Top 10 Contribution on Genetics.

57. Fu QY, Li QS, Lin XM, Qiao RY, Yang R, et al. (2017) Antidiabetic effects of tea. Molecules 22(5): 849.

58. Du LL, Fu QY, Xiang LP, Zheng XQ, Lu JL, et al. (2016) Tea polysaccharides and their bioactivities. Molecules 21(11): 1449. 